DOI: $10.34185 / 1991-7848.2021 .01 .11$

УДК 669.02

А.А. Самсоненко, В.І. Гануш, С.В. Бергеман ${ }^{11}$

\title{
ДОСЛІДЖЕННЯ ПІДШИПНИКІВ РІДИННОГО ТЕРТЯ РОБОЧИХ КЛІТЕЙ 630 СТАНУ 550
}

\begin{abstract}
Аналіз експлуатації підшипників рідинного тертя (ПРТ) станів 630 показав, що втрати мастила на клітях 630 досягають до 10 тонн за рік. Причиною цього $\epsilon$ недосконалість конструкції ущільнення, а це в свою чергу не забезпечує необхідний режим змащування ПРТ і призводить до високоінтенсивного зносу поверхонь втулки та вкладиша підшипника. Що призводить до виходу з ладу ПРТ раніше встановленого строку заміни втулки та вкладиша.
\end{abstract}

Метою дослідження є визначення навантаженості ПРТ шляхом математичного моделювання для визначення енерго-силових параметрів прокатки на прикладі швелеру № 14, визначення коефіцієнту тертя, дослідження процесу зносу поверхні втулки та вкладиша ПРТ та надання рекомендації, щодо можливого шляху удосконалення ущільнення ПРТ клітей 630. Розрахунок піддвердив перехід до граничного тертя при зносі до радіального зазору в 4 мм, що спостерігалось при експлуатації ПРТ. Запропонована удосконалена конструкція ущільнень 3 використанням V-подібних манжет.

Ключові слова: робоча кліть, підшипник рідинного тертя, моделювання, метод скінчених елементів, зусилля прокатки, коефіцієнт тертя, знос, ущільнення

\section{Постановка проблеми}

Як відомо до складу сортового стану 550, який призначений для виробництва періодичних профілей методом поздовжньої прокатки, входять сім робочих клетей 630. Валки в цих клітях встановлено на підшипниках рідинного тертя (ПРТ). В процесі експлуатації ПРТ було виявлено загальні втрати мастила на сімох клітях 630 до 10 тонн за рік. Причиною цього є недосконалість конструкції ущільнення, а це в свою чергу не забезпечує режим змащування ПРТ і підшипник виходить з ладу раніше встановленого строку експлуатації. Тому необхідність дослідження робочих параметрів ПРТ $є$ актуальною задачею.

\section{Мета дослідження}

Метою дослідження $\epsilon$ визначення навантаженості ПРТ, визначення коефіцієнту тертя, дослідження процесу зносу поверхні втулки та вкладиша ПРТ та надання рекомендації, щодо можливого шляху удосконалення ущільнення ПРТ.

(c) Самсоненко А.А., Гануш В.І., Бергеман С.В., 2021 


\section{Навантаженість ПРТ}

Для визначення навантаженості ПРТ необхідно знайти енерго-силові параметри прокатки в клітях 630. Для цього обираємо швелерний профіль №14. Для визначення енерго-силових параметрів процесу прокатки швелерного профілю було проведено математичне моделювання 3 використанням програмного продукту QForm 9 (виконано на кафедрі OMT НМетАУ в рамках угоди про використання програми QForm No. MSL2015_10_5 від 28.10.2015 р.). Програма QForm призначена для математичного моделювання, на основі методу скінчених елементів, технологічних процесів обробки металів тиском з урахуванням термомеханічних процесів нагріву та охолодження металу, в тому числі у процесі деформації, а також взаємодії заготовки, що деформується, 3 технологічним інструментом та обладнанням [1]. Математичною основою програми є система рівнянь, яка включає рівняння рівноваги, рівняння зв’язку між полем швидкостей матеріальних точок та швидкостей деформації, рівняння зв'язку між напруженим та деформованим станом, умови нестиснення, критерій пластичності, рівняння енергетичного балансу [2, 3].

Моделювання було проведено для умов прокатки швелеру № 14 в клітях № 2 - 8 стана 550 ПрАТ «Дніпровський металургійний завод». Було прийнято наступні вихідні дані:

- габаритні розміри заготовки після розрізного калібру $(\mathrm{h} \times \mathrm{b})$ - 105× 120 мм;

- температура нагріву заготовки в печі - $1200{ }^{\circ} \mathrm{C}$;

- матеріал заготовки - сталь 09Г2С;

- швидкість обертання валків -60...120 об/хв;

- середній діаметр валків - 700 мм.

Умови тертя в контакті інструменту та заготовки було задано моделлю Леванова з фактором тертя 0,8.

Загальний вигляд моделі для 7 проходу (кліть № 7) наведено на рисунку 1. Розподіл сили прокатки по клітях наведено на рисунку 2.

Як бачимо, найбільші зусилля прокатки і відповідно навантаження на ПРТ будуть діяти в кліті №4 та досягати при захваті розкату 2,8 МН. Найменші зусилля прокатки і відповідно навантаження на ПРТ будуть діяти в кліті №8 та досягати при захваті розкату $1,1 \mathrm{MH}$. 


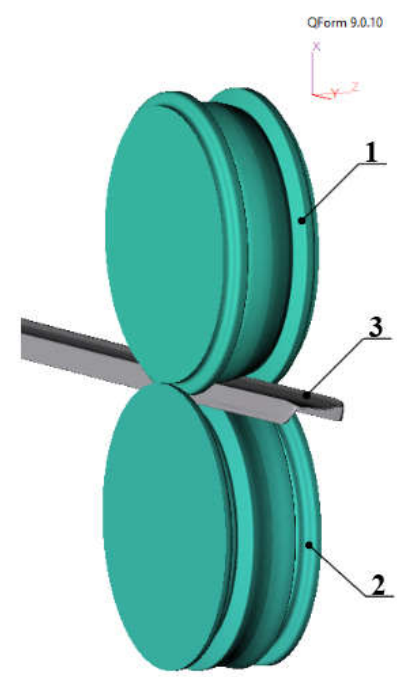

1 - верхній валок, 2 - нижній валок, 3 - розкат

Рисунок 1 - Загальний вигляд моделі прокатки швелерного профілю в 7 проході

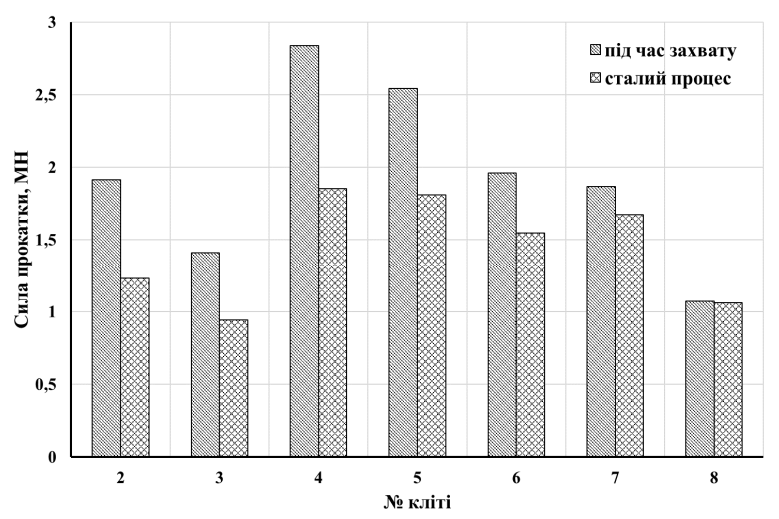

a)

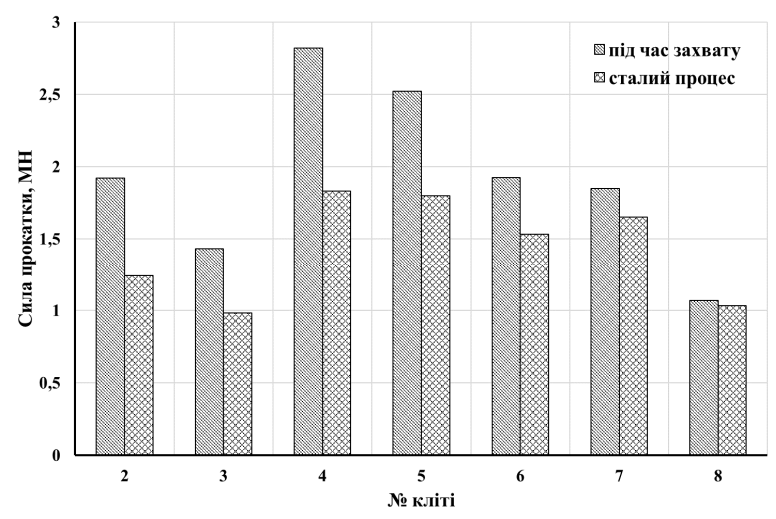

б)

Рисунок 2 - Розподіл сили прокатки по клітях для умов захвату та сталого процесу: а - верхній валок, б - нижній валок

\section{Визначення коефіцієнту тертя}

Коефіцієнт тертя для підшипника рідинного тертя визначається, як [4]

$$
\mu=\pi \cdot \eta \cdot \frac{u}{\delta \cdot p}+\frac{\delta}{d_{u}},
$$

де $\eta$ - динамічна в'язкість масла (для мінерального масла УТ при температурі підшипника $50^{\circ} \mathrm{C}$ ), Па·с; u - швидкість ковзання цапфи підшипника, м/с; $\delta$ - радіальний зазор, м; p - середній тиск в підшипнику, Па; $\mathrm{d}_{\Perp}$ - діаметр цапфи підшипника, м.

Середній тиск в підшипнику [4]

$$
p=\frac{Y}{l \cdot d_{u}}, \text { МПа. }
$$

тут Y - навантаження, що діє на ПРТ (спрощено приймаємо, як половину зусилля прокатки), Н; 1 - довжина втулки подшипника, м. 
Кінематична в'язкість мінерального масла УТ при температурі підшипника $50^{\circ} \mathrm{C}-v=29,75 \cdot 10^{-6} \mathrm{M}^{2} / \mathrm{c}$.

Динамічна в'язкість мінерального масла УТ при температурі підшипника $50^{\circ} \mathrm{C}$

$$
\eta=v \cdot \rho=29,75 \cdot 10^{-6} \cdot 898,2=0,0267 \Pi a \cdot c .
$$

де $\rho$ - щільність масла, кг/м³.

Швидкість ковзання цапфи підшипника

$$
u=\omega \cdot r_{u}=\frac{2 \cdot v}{D} \cdot r_{u}=\frac{2 \cdot 7}{0.63} \cdot 0,5 \cdot 0.45=5 \mathrm{M} / \mathrm{c} .
$$

де $\omega$ - кутов ашвидкість валків, $\mathrm{c}^{-1} ; v$ - швидкість прокатки, м/с; D - діаметр валка, м.

В таблиці 1 наведено результати розрахунку середнього тиску та коефіцієнту тертя в ПРТ клітей 630 при захваті розкату. Отриманий результат свідчить, що збільшення навантаження, що діє на підшипник не суттєво впливає на зміну коефіцієнта тертя в ньому, який знаходитья в межах 0,0027 - 0,00274.

Найбільше на величину коефіцієнта тертя $\mu$ будуть впливати в'язкість масла $\eta$ та величина радіального зазору $\delta$.

Таблиця 1

Середіній тиск та коефіцієнт тертя в клітях 630

\begin{tabular}{|l|l|l|l|}
\hline № кліті & Зусилля прокатки, МН & Середній тиск р, МПа & Коефіцієнт тертя $\mu$ \\
\hline 2 & 1,914 & 5,8 & 0,00273 \\
\hline 3 & 1,41 & 6,3 & 0,00272 \\
\hline 4 & 2,836 & 4,6 & 0,00274 \\
\hline 5 & 2,544 & 9,3 & 0,00270 \\
\hline 6 & 1,962 & 8,3 & 0,00271 \\
\hline 7 & 1,868 & 6,4 & 0,00272 \\
\hline 8 & 1,072 & 6,1 & 0,00272 \\
\hline
\end{tabular}

Розглянемо, як впливає збільшення зазору з номінального до допустимого на коефіцієнт тертя ПРТ для кліт №4, результати занесено до таблиці 2.

При збільшені зазору з 1,2 мм до 1,8 мм, коли за правилами експлуатації ПРТ [5] необхідно замінювати пару втулку-вкладиш коефіцієнт тертя збільшується на 48\% з 0,0027 до 0,004. А при катастрофічному зносі до зазору в 3 та 4 мм коефіцієнт тертя збільшується до 0,007 та 0,009, тобто приймає значення, при яких настає гранічне тертя. 
Таблиця 2

Результати розрахунка зміни коефіцієнта тертя при збільшені зазору

\begin{tabular}{|l|l|l|}
\hline № & Зазор $\delta$, мм & Коефіціснт тертя $\mu$ \\
\hline 1 & 1,2 & 0,0027 \\
\hline 2 & 1,3 & 0,0029 \\
\hline 3 & 1,4 & 0,0031 \\
\hline 4 & 1,5 & 0,0034 \\
\hline 5 & 1,6 & 0,0036 \\
\hline 6 & 1,7 & 0,0038 \\
\hline 7 & 1,8 & 0,004 \\
\hline 8 & 3 & 0,007 \\
\hline 9 & 4 & 0,009 \\
\hline
\end{tabular}

\section{Визначення зносу втулки підшипника}

Однією 3 характеристик роботи втулки та вкладиша підшипника рідинного тертя є знос їх поверхонь (рис. 3) та інтенсивність зносу.

Граничний знос деталі або граничний зазор в з'єднанні часто визначають по кривій залежності зносу деталі або зміни зазору в з'єднанні внаслідок зносу від напрацювання.
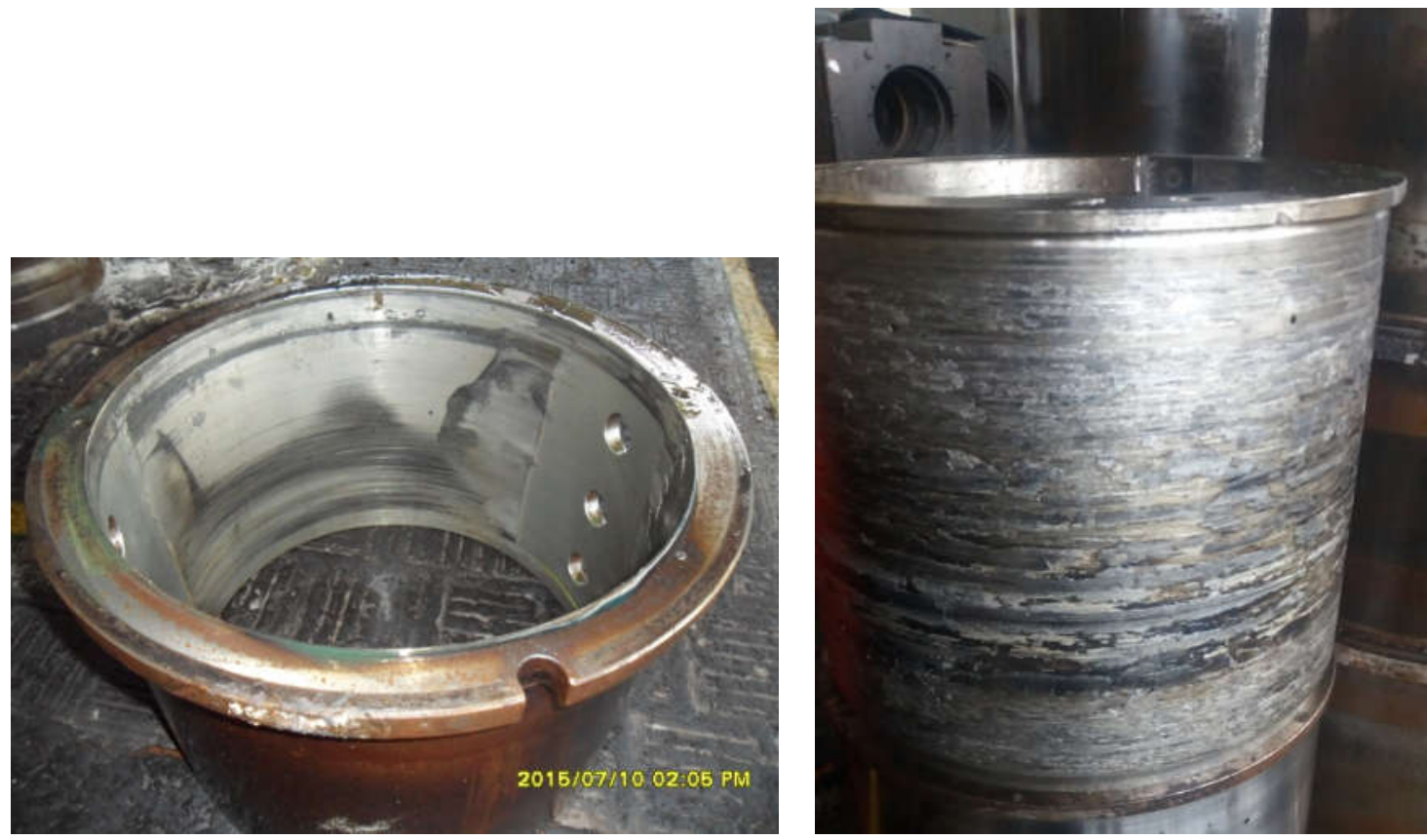

Рисунок 3 - Фотограції зносу поверхонь втулки та вкладиша ПРТ кліті 630

Величина зносу поверхні підшипника [6]

$$
\Delta_{i}=\Delta_{0}+I \cdot S_{i}
$$

Де $\Delta_{0}$ - початковий розмір деталі, в нашому випадку початковий зазор $\delta=1,2$ мм=1200 мкм; I - інтенсивність зносу; $S_{i}$ - шлях тертя, мкм. 
Шлях тертя вкладиша підшипника рідинного тертя за 1 оберт

$$
S_{1}=\pi \cdot D=\pi \cdot 0.45=1,4137 \text { м }=1413717 \text { мкм. }
$$

Час роботи стана приймаємо - $\mathrm{t}=8000$ годин.

Число обертів валка $\mathrm{n}=212$ об/хв = 12720 об/годину.

Максимальне число обертів n=1000 об/хв = 60000 об/годину.

Тоді загальний шлях тертя за рік

$$
S_{i}=S_{1} \cdot t \cdot n=1413717 \cdot 8000 \cdot 60000=6.8 \cdot 10^{14} \text { мKM. }
$$

Величина зазору при зносі поверхні вкладиша за 1 рік

$$
\delta_{i}=1200+10^{-13} \cdot 6,8 \cdot 10^{14}=1268 \mathrm{MKM}=1,268 \mathrm{MM} .
$$

Довговічність [6]

$$
T=\frac{[\delta]-\delta_{0}}{I \cdot v_{s}},
$$

Де [б] - допустимий зазор, мкм; $\mathrm{v}_{\mathrm{s}}$ - швидкість пересування втулки и вкладиша відносно один одного, мкм/год.

$$
\begin{gathered}
v_{s}=\frac{S_{i}}{t}=\frac{6.8 \cdot 10^{14}}{8000}=8.5 \cdot 10^{10} \text { мкм / годину. } \\
T=\frac{1800-1200}{10^{-13} \cdot 8,5 \cdot 10^{10}}=70588 \text { годин. }
\end{gathered}
$$

При роботі в 8000 годин за рік, $\mathrm{T}=8,8$ року.

Таким чином величину зазору $\delta=1,8$ мм, при досягнені якого замінюють вкладиш та втулку підшипника буде отримано через 8,8 років експлуатації. Але експлуатаційні дані свідчать про те, що такого зазору досягають за 3 роки роботи. Зниження строку експлуатації підшипника пояснюється невідповідним режимом тертя, а саме не дотриманням параметрів в’язкості масла та його недостатньою кількістю в підшипнику. Причиною цього є витікання масла через ненадійне ущільнення та потрапляння в нього абразиву та охолоджувальної рідини валків.

\section{Удосконалення ущільнень ПРТ}

Шляхом уникнення вказаних недоліків $\epsilon$ удосконалення ущільнень ПРТ кліті 630 (рис. 4). Ущільнювальну функцію тут здійснюють V-подібні манжети [7], встановлені на насадці, закріпленої на втулці-цапфі валка і контактуючі із плоскими контактними поверхнями задньої кришки. Захист від потоку охолоджувальної рідини, забезпечується манжетою типу РНСТ. Додатковий захист від проникнення в підшипник рідини дають жолобки на зовнішній поверхні обертової частини лабіринтового ущільнення. Вода накопичується в жолобку-уловлювачі, який перебуває напроти в нерухливій 
частині лабіринтового ущільнення й стікає вниз через дренажний отвір. Також встановлюємо армовану манжету на ліву опору після жолобків.

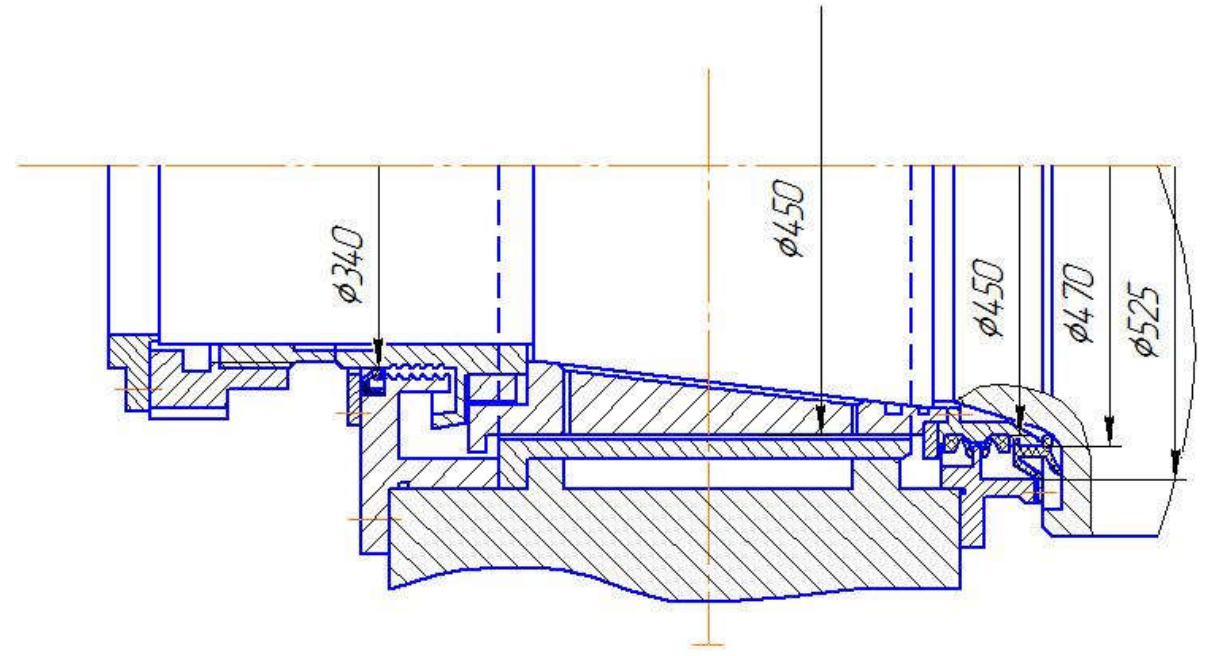

Рисунок 4 - Креслення нового ущільнення ПРТ кліті 630

\section{Висновок}

Аналіз експлуатації ПРТ станів 630 показав, що втрати мастила на клітях 630 досягають до 10 тонн за рік. Причиною цього є недосконалість конструкції ущільнення, а це в свою чергу не забезпечує необхідний режим змащування ПРТ і призводить до високоінтенсивного зносу поверхонь втулки та вкладиша підшипника. Що призводить до виходу з ладу ПРТ раніше встановленого строку заміни втулки та вкладиша. Проведено математичне моделювання для визначення енерго-силових параметрів прокатки на прикладі швелеру №14 для визначення навантаженості ПРТ. Досліджено коефіцієнт тертя в ПРТ клітей 630. Отриманий результат свідчить, що збільшення навантаження, що діє на підшипник не суттєво впливає на зміну коефіцієнта тертя в ньому, який знаходитья в межах 0,0027 - 0,00274. Найбільше на величину коефіцієнта тертя $\mu$ будуть впливати в'язкість масла $\eta$ та величина радіального зазору $\delta$. Розрахунок піддвердив перехід до граничного тертя при зносі до радіального зазору в 4 мм, що спостерігалось при експлуатації ПРТ. Запропонована конструкція ущільнень з використанням V-подібних манжет.

\section{ЛITЕРАТУРА}

1. QForm - Software for simulation and optimization of metal forming processes and metal profile extrusion, QFX Simulations Ltd., http://www.qform3d.com/

2. Gerasimov D., Biba N.,Stebunov S.,Kadach M. Implementation of a dual mesh method for longitudinal rolling in QForm V8. International Conferenceon Productionand Further Processing of FlatProducts, MEFORM 2016. 2016. V. 854. P. 158-162. DOI: 10.4028/www.scientific.net/MSF.854.158 
3. Власов А.В., Стебунов С.А., Евсюков С.А.,Биба Н.В., Шитиков А.А. Конечно-элементное моделирование технологических процессов ковки и объемной штамповки: учеб. пособие. М. :Изд-во МГТУ им. Н.Э.Баумана, 2019.- 383 с. ISBN 978-5-7038-5101-2.

4. Королев А. А. Конструкция и расчет машин и механизмов прокатных станов. - М.: Металлургия, 1985. - 376 с.

5. ДСТу 22915-88. Подшипники жидкостного трения. Правила эксплуатации. М.:Издательство стандартов, 1988, 32 с.

6. И. В. Крагельский, М.Н. Добычин, В.С. Комбалов. Основы расчетов на трение на износ. - М.: Машиностроение, 1977. - 350 с.

7. Уплотнения и уплотнительная техника. Справочник. /под. ред. А. И. Голубева, Л. А. Кондакова. - М.: Машиностроение, 1986. - 464 с.

\section{REFERENCES}

8. QForm - Software for simulation and optimization of metal forming processes and metal profile extrusion, QFX Simulations Ltd., http://www.qform3d.com/

9. Gerasimov D., Biba N.,Stebunov S.,Kadach M. Implementation of a dual mesh method for longitudinal rolling in QForm V8. International Conferenceon Productionand Further Processing of FlatProducts, MEFORM 2016. 2016. V. 854. P. 158-162. DOI: 10.4028/www.scientific.net/MSF.854.158

10.Vlasov A.V., Stebunov S.A., Evsyukov S.A., Biba N.V., Shitikov A.A. Finite-element modeling of technological processes of forging and volumetric stamping: textbook. allowance. M.: Publishing house of MSTU im. N.E.Bauman, 2019. - 383 p. ISBN 978-5-7038-5101-2.

11. Korolev AA Design and calculation of machines and mechanisms of rolling mills. - M .: Metallurgy, 1985 . - $376 \mathrm{p}$.

12.DSTU 22915-88. Liquid friction bearings. Operating rules. - M.: Publishing house of standards, 1988, $32 \mathrm{p}$.

13.I. V. Kragelsky, M. N. Dobychin, V.S. Kombalov. Fundamentals of Friction Wear Calculations. - M .: Mashinostroenie, 1977 . - $350 \mathrm{p}$.

14. Seals and sealing technology. Directory. /under. ed. A.I. Golubeva, L.A. Kondakova. - M .: Mashinostroenie, 1986 - $464 \mathrm{p}$.

Received 20.01.2021. Accepted 29.01.2021.

UDC 669.02

A. Samsonenko, V. Hanush, S. Berheman

\section{RESEARCH OF FLUID FRICTION BEARINGS OF WORKING STANDS 630 OF ROLLING MILL 550}

Analysis of the operation of fluid friction bearings (FFB) of mills 630 showed that the loss of oil on the cages 630 reaches up to 10 tons per year. The reason for this is the imperfection of the seal design, which in turn does not provide the required mode of lubrication of the FFB and leads to high-intensity wear of the surfaces of the sleeve and bearing liner. Which leads to the failure of the FFB before the deadline for replacement of the sleeve and liner. The aim of the study is to determine the load of FFB by mathematical modeling to determine the energy and power parameters of rolling on the example of channel №14, determine the coefficient of friction, study the wear of the surface of the sleeve and liner FFB and provide recommendations for possible ways to improve FFB seals 630. To determine the energy and power parameters of the rolling profile of the channel profile, mathematical modeling was performed using the software product QForm 9. The QForm program is designed for mathematical modeling, based on the finite element 
method, technological processes of metal forming by taking into account thermomechanical processes of heating and cooling of metal, including in the process of deformation, as well as the interaction of the deformable workpiece with technological tools and equipment. The greatest rolling forces and, accordingly, the load on the FFB will act in the cage №4 and reach 2.8 $\mathrm{MN}$ when the roll is captured. The obtained result indicates that the increase in the load acting on the bearing does not significantly affect the change in the coefficient of friction in it, which is in the range of $0.0027-0.00274$. The value of the friction coefficient $\mu$ will be most affected by the viscosity of the oil $\eta$ and the value of the radial gap $\delta$. The calculation confirmed the transition to the maximum friction during wear to a radial gap of $4 \mathrm{~mm}$, which was observed during the operation of the FFB. The value of the gap $\delta=1.8 \mathrm{~mm}$, at which the replacement of the liner and the bearing sleeve will be obtained after 8.8 years of operation. But operational data show that such a gap is reached in 3 years of operation. The reduction in bearing life is due to inadequate friction, namely non-compliance with the viscosity parameters of the oil and its insufficient amount in the bearing. The reason for this is the leakage of oil due to unreliable sealing and ingress of abrasive and coolant rolls. An improved design of seals using V-shaped cuffs is proposed.

Keywords: working stand, fluid friction bearing, modeling, finite element method, rolling force, coefficient of friction, wear, sealing.

Самсоненко Андрій Анатолійович - доцент кафедри Обробки металів тиском, Національна металургійна академія України.

Гануш Василь Іванович - старший викладач кафедри Машин та агрегатів металургійного виробництва, Національна металургійна академія України.

Бергеман Сергій Володимирович - керівник ділянки з підготовки та ремонту прокатних валків прокатного цеху №2, ПрАТ «Дніпровський металургійний завод».

Samsonenko Andrii - candidate of technical science, assistant professor, Department of metal forming, The National Metallurgical Academy of Ukraine.

Hanush Vasyl - senior teacher, Department of metallurgical production machines and units, The National Metallurgical Academy of Ukraine.

Berheman Sergiy - head of the section for the preparation and repair of rolls of rolling shop No. 2, JSC "Dneprovsky Metallurgical Plant". 